\title{
Tanulmányok
}

\section{SORSA NAGYOBB VOLT NÁLA: ANDREJ D. SZAHAROV}

\section{HIS FATE WAS LARGER THAN HIM: ANDREI D. SAKHAROV}

\author{
Hargittai István \\ az MTA rendes tagja, Budapesti Múszaki és Gazdaságtudományi Egyetem \\ istvan.hargittai@gmail.com
}

\section{ÖSSZEFOGLALÁS}

A szovjet hidrogénbomba atyjaként is számon tartott világhírű fizikus és emberjogi harcos, Andrej D. Szaharov (1921-1989) mondotta magáról: „sorsom nagyobb lett, mint ami személyiségemből következett volna. Én csupán igyekeztem méltónak bizonyulni sorsom alakulásához." Életének és munkásságának sok elgondolkoztató vonatkozása és tanulsága van, amelyek közül a következőket emelem ki ebben az írásban: - A szovjet diktatúrában a rendszer számára fontos tudomány és technológia művelőit a rendszer megkülönböztetett figyelemben részesítette. Azonban még nekik sem engedte meg, hogy véleményük megjelenhessen a politika alakításában. - Hogyan kényszerítették a kísérleti nukleáris robbantások lehetséges következményei a korábban kizárólag tudományos kérdésekkel foglalkozó Szaharovot politikai állásfoglalásra? - Hogyan fejlődhet valaki egy rendszer feltétlen támogatójából a rendszer engesztelhetetlen kritikusává? - Egy nagy tudós még a legsanyarúbb körülmények között is talál lehetőséget alkotó munkára. - Mi jellemezte Szaharov és Gorbacsov kapcsolatát? - Miben volt hasonló és miben különbözött Andrej Szaharov és Teller Ede? - Szükség lehet-e új Szaharovokra?

\section{ABSTRACT}

The world-renowned physicist, known also as 'the father of the Soviet hydrogen bomb', Andrei D. Sakharov (1921-1989), was also a fierce fighter for human rights. In his words, '... my fate was larger than what would have followed from my personality. I was merely trying to be worthy of my fate ...' His life and his body of work contain many thought-provoking lessons and associations, of which I feature the following in this article: - The Soviet dictatorship granted privileges to researchers who worked in selected areas of science and technology important for the regime. However, even they were barred from participation in shaping the policy of the country. - How did hard facts concerning the consequences of nuclear testing force Sakharov to take a political stand? - How did Sakharov develop from a dedicated supporter of the regime into its relentless critic? - Even under the most unfavorable circumstances Sakharov produced good science. - Interactions between Sakharov and Mikhail Gorbachev. - Similarities and differences between Andrei Sakharov and Edward Teller. - Is there a need for new Sakharovs today? 
Kulcsszavak: Andrej Szaharov, hidrogénbomba, fúziós reaktor, barion-aszimmetria, Mihail Gorbacsov, Teller Ede

Keywords: Andrei Sakharov, hydrogen bomb, fusion reactor, baryon asymmetry, Mikhail Gorbachev, Edward Teller

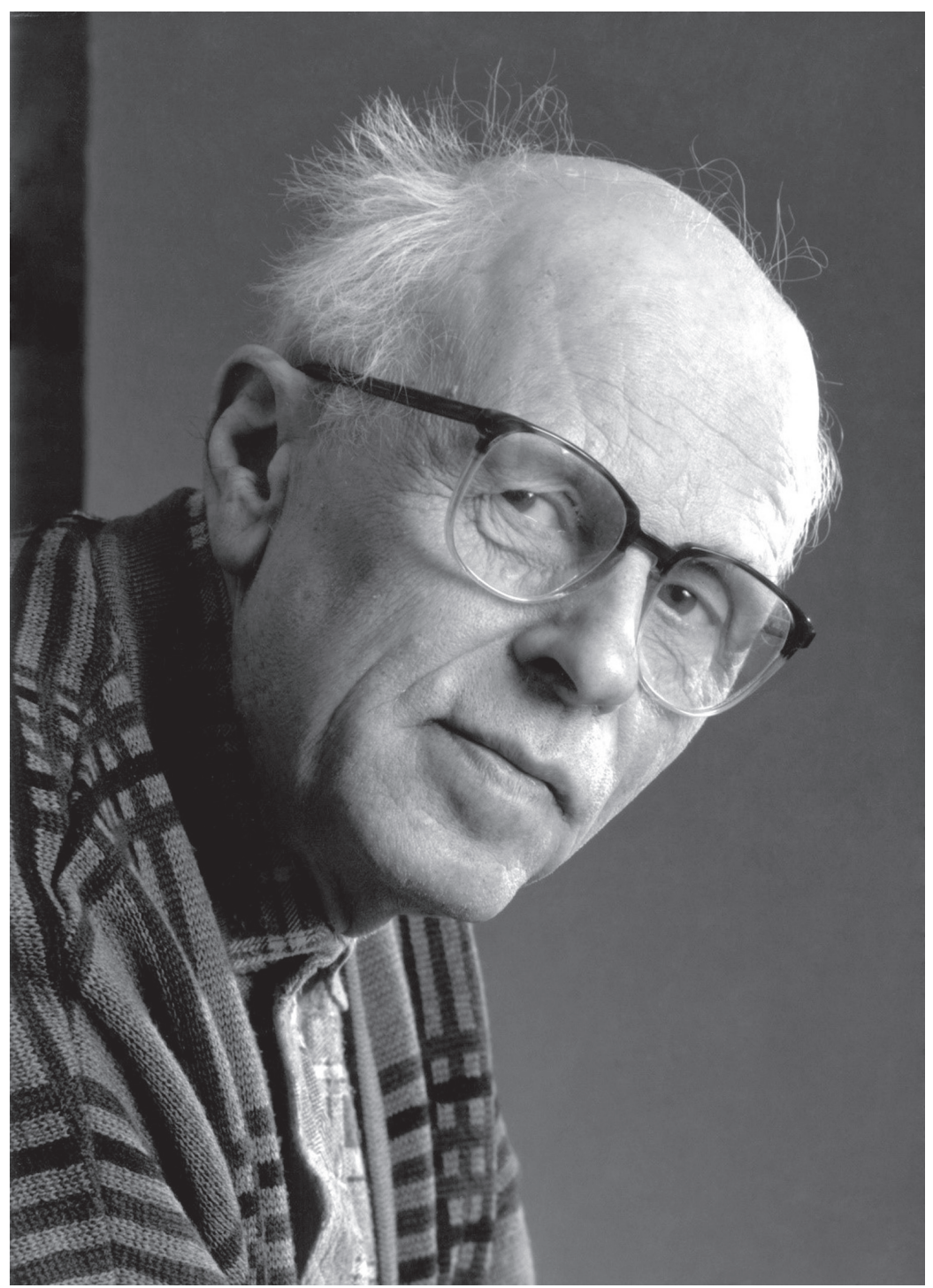

Andrej Szaharov 1989-ben, Yousuf Karsh felvétele

(C) Yousuf Karsh / Camera Press) 


\section{EGY TUDÓS A SZOVJET DIKTATÚRÁBAN}

Andrej D. Szaharov (1921-1989) moszkvai értelmiségi családba született. Apja fizikus volt, tankönyveket és fizikát népszerüsítő könyveket írt, és ismerte az egyik vezető tudóst, a későbbi Nobel-díjas Igor Tamm fizikust, a Szovjet Tudományos Akadémia (SZUTA) Lebegyev Fizikai Kutató Intézetének (FIAN) ${ }^{1}$ vezető teoretikusát. Ez az ismeretség később segítette Szaharov elindulását a kutatói pályán. Andrej az M. V. Lomonoszov Moszkvai Állami Egyetemen tanult fizikusnak. Amikor a háború idején az Egyetemet Türkmenisztánba evakuálták, a képzés továbbra is magas szinten folyt. A végzés után egy hadiüzemben dolgozott, ahol lövedékeket gyártottak. Itt újításaival tủnt ki. A háború után tudása alapján kiérdemelte és Tamm ismeretsége meg is hozta számára a lehetőséget, hogy a FIAN-ban kezdhesse el kutatói pályáját.

Szaharov szerencsés volt, mert nem érték el a különböző sztálini terrorhullámok, amelyek például az elméleti fizikus Lev Subnyikov, a világhírü biológus Nyikolaj Vavilov, vagy éppen Tamm mérnök testvérének meggyilkolását, a későbbi Nobel-dijas elméleti fizikus Lev Landau börtönbe vetését és megkínoztatását, számos későbbi kiváló tudós, mérnök, tervező munkatáborba zárását okozták.

Amikor arra sor került, senki sem kérdezte meg töle, hogy akar-e hidrogénbombát készíteni, a szovjet tudósoknak nem volt szabad választásuk. Tamm munkatársaként zokszó nélkül elköltözött a titkos atomvárosba, Szarovba, és két évtizedig ott is maradt. Mire Tamm és Szaharov megérkezett az Arzamasz-16 laboratóriumba, már nem volt dolguk az atombombával, és a hidrogénbombára összpontosították figyelmüket. Attól kezdve, hogy Szaharovot bekapcsolták ebbe a munkába, magával ragadta a feladat fontossága, és lelkesen, lelkiismeretesen és eredményesen vett benne részt. Csak harmincnégy évvel később, belső számüzetése idején érezte azt, hogy ezt a lelkes részvételt meg kell magyaráznia, ezzel el kell számolnia, éspedig elsősorban saját maga felé. Az, hogy ez ,jó fizika” volt, amint erre alább is utalok, aligha adott kielégitő magyarázatot. Szaharov, ahogy mestere, Tamm is, meg volt győződve arról, hogy erre a munkára, erre a borzalmas fegyverre szükség van, elengedhetetlenül szükség van. A 2. világháborúban, melyet az oroszok ma is Nagy Honvédő Háborúként emlegetnek, Szaharov nem szolgált katonaként. Most úgy érezte, katonaként kell helyt állnia ebben a tudományos-technológiai háborúban. A meggyőződés inkább volt érzelmi, mint intellektuális.

A szovjet hidrogénbomba megvalósításához vezető három alapötlet közül kettő elsősorban Szaharov nevéhez füződik, egy pedig a későbbi Nobel-díjas Vitalij Ginzburg nevéhez. Ginzburg is a FIAN munkatársa volt, de csak rövid ideig vett

\footnotetext{
${ }^{1}$ Fizicseszkij Insztyitut Akagyemii Nauk.
} 
részt a hidrogénbomba kifejlesztésében. Nem tekintették elég megbízhatónak, nem lehetett az Arzamasz-16 munkatársa, és rövidesen már Moszkvában sem folytathatta ezt a munkát.

Szaharov kandidátusi disszertációjának védésére 1947. november 3-án került sor a FIAN-ban. A disszertáció az atommagban lejátszódó átmenetek elméletéről szólt. A védésen a SZUTA elnöke, Szergej Vavilov akadémikus elnökölt. A két opponens két későbbi akadémikus, Arkagyij Migdal és Iszaak Pomerancsuk volt. A vitában Tamm és Grigorij Landszberg akadémikus szólalt fel. Tamm kiemelte, hogy Szaharov két olyan tulajdonságot testesít meg, amely nagyon fontos az elméleti fizikusok számára, de együtt ritkán jelentkezik. Az egyik a felmerülő probléma kvalitatív megértése és áttekintése, a másik a probléma egzakt matematikai kezelése. A Tudományos Tanács egyhangúlag szavazta meg a kandidátusi fokozat odaítélését Szaharovnak.

Szaharov „nagydoktori” fokozatát már a titkos nukleáris laboratóriumban szerezte meg 1953-ban - a védésre júniusban került sor - a hidrogénbomba elkészítésén folyó lázas munka idején. Szaharov emlékiratai szerint a szovjet atomcár, Igor Kurcsatov kezdeményezésére Szaharovnak már 1953 tavaszán össze kellett állítania az akadémiai levelező tagságához szükséges dokumentumokat. Akkor még hiányzott az akadémikussá történő megválasztásához kötelezően előírt „nagydoktori fokozata”. Ezt a hiányt pótolták júniusban. Az Arzamasz-16 titkos laboratórium Tudományos Tanácsának speciális ülésén kapta meg Szaharov a fizikai és matematikai tudományok doktora fokozatot az általa bemutatott tézisek (kutatási eredmények összefoglalása, peферат) alapján. A bemutatott munka értékelésére két hivatalos opponensi véleményről tudunk. Igor Tamm recenziója nem került nyilvánosságra, azt Szaharov magánlevéltára örzi. Ezen a véleményen nincs dátum, és a vélemény nem sorolja fel a jelölt tudományos eredményeit. A másik véleményt Julij Hariton, az Arzamasz-16 tudományos vezetője készítette, és ez húzásokkal meg is jelent. Furcsa módon ennek dátuma 1953. november 9., mintha már az akadémikusi választások után készült volna. Hariton véleménye Szaharovnak a termonukleáris berendezés kialakításával kapcsolatos eredményeit említi meg. ${ }^{2}$ Szaharov tudományos kvalitásait kandidátusi munkája és védése bizonyította, és senki sem csodálkozott volna azon, ha akkor egyböl megkapja a nagydoktori fokozatot. Azonban az 1953-as nagydoktori eljárás nyilvánvaló sietséggel történt az első szovjet termonukleáris berendezés kísérleti robbantására történő lázas készülődés közepette. Az első szovjet termonukleáris szerkezetet, amely még nem volt igazi bomba, 1953. augusztus 12-én robbantották fel, óriási sikerrel. Ennek döntő szerepe volt abban, hogy Szaharovot nem is levelező tagnak, hanem, felsőbb utasításra egy-

\footnotetext{
${ }^{2}$ Köszönettel tartozom dr. Alekszandr Vernijnek, Szaharov fizikus és tudománytörténész vejének a témában 2020 februárjában nyújtott segítségéért.
} 
ből rendes tagnak választották meg. ${ }^{3}$ Hivatalosan a SZUTA Közgyülése 1953. október 23-án választotta be a SZUTA rendes tagjai közé. Néhány hónappal később Szaharovot kitüntették a Szocialista Munka Höse címmel. Ezt a legrangosabb kitüntetést még kétszer kapta meg, 1956-ban és 1962-ben, mindkét alkalommal újabb sikeres kísérleti nukleáris robbantások nyomán. Szaharov lett az egyik legmagasabban elismert szovjet tudós, akit a (szovjet) hidrogénbomba atyjaként emlegettek, és akinek valóban döntő szerepe volt a szovjet szuperhatalmi státusz elérésében.

Szaharov első összeütközésére a felsőbbségekkel 1955-ben került sor. Egy kísérleti robbantás után - ez volt az első igazi szovjet hidrogénbomba - rendezett ünnepségen pohárköszöntöjében annak a reménynek adott kifejezést, hogy sikeres robbantásaikat mindig csak kísérleti helyszínek és sohasem városok felett fogják végrehajtani. Minden jelenlevő megérezte, hogy a fizikus ezzel a megjegyzésével problémás területre tévedt, és a hatalom jelen levő képviselöje durva tanmesével oktatta ki. A tanmese a hatalom figyelmeztetését közvetítette a fizikus felé, hogy a politikát hagyja a politikusokra. Ez volt az első, de nem az utolsó eset, amikor Szaharovnak tudomására hozták, hol a helye. Amikor a Szovjetunió a világ addigi legnagyobb bombájának a felrobbantására készülődött, az akkori szovjet vezető, Nyikita Hruscsov 1961 júliusában tanácskozásra hívta az atomtudósokat. Szaharov ekkor arról beszélt, hogy nincs várható hozadéka az egyre nagyobb bombák hadrendbe állításának, míg a további kísérleti robbantások különféle veszélyekkel járnak. Ez alkalommal a legfelső szovjet vezető oktatta ki a legnagyobb szovjet atomtudóst, és alázta meg tudós és politikus közösség jelenlétében.

Szaharov még ezek után is folytatta a munkát az Arzamasz-16 laboratóriumban, és csak 1968-ban tért vissza Moszkvába, miközben teljesen elidegenedett a projekttől. Hozzáállását nem érzelmei határozták meg. Már az 1950-es évek közepétől aggódott a kísérleti robbantások esetleges biológiai következményei miatt. Fiatalkora óta érdekelte a genetika, és tisztában volt azzal, hogy a nukleáris robbantások biológiai következményei „küszöb nélküli” események, vagyis nincs olyan minimális dózis, amely alatt már kizárhatók lennének. Érdeklődését csak erősítette a szovjet biológia tarthatatlan helyzete. Más fizikusok és kémikusok is egyre jobban érezték, hogy tenniük kell a liszenkóizmussal ellehetetlenített állapotok megváltoztatásáért.

Ugyanakkor ebben az időben történt valami, ami jól mutatja, milyen ellentmondások között vergődött Szaharov, egyrészt az általa kifejlesztett egyre nagyobb erejü bombák, másrészt az általuk képviselt borzalmas veszélyek hatása alatt. Bármennyire is ellenezte a kísérleti robbantások folytatását és az egyre nagyobb erejü bombák létrehozását, közben az is foglalkoztatta, hogyan lehetne

\footnotetext{
${ }^{3}$ Egyetlen másik fizikus esetében történt ilyen lépés korábban, amikor Sztálin közvetlen beavatkozására Igor Kurcsatovot 1943-ban egyből akadémiai rendes tagnak választották meg.
} 
azokat a leghatékonyabban felhasználni. A legnagyobb, az ún. Cár bomba kísérleti felrobbantása után Szaharov a haditengerészet egyik vezetöjének javaslattal állt elö, amely szerint egy hatalmas, nukleáris töltettel felszerelt torpedót lehetne kilőni egy tengeralattjáróról, amellyel egy akár több száz kilométerre található ellenséges kikötőt céloznának meg. A haditengerészet szakértői szerint a torpedó hatalmas pusztítást eredményezne, és megsemmisítené a kikötőt. Ha nem Szaharov emlékirataiban olvasnánk erről a javaslatáról, nehéz lenne elhinni, hogy valóban élhetett ilyen javaslattal. Ez a példa jól érzékelteti, honnan indult el Szaharov azon az úton, amely aztán a szovjet rendszer legkövetkezetesebb kritikusává és egyik legelszántabb emberjogi harcosává tette.

\section{ÁTMENET}

Szaharov becsléseket végzett, amelyekben figyelembe vette a kísérleti robbantások nyomán keletkező radioaktív izotópok hosszú távú hatását is. Becslései szerint minden megatonna (egymillió tonna) TNT-ekvivalens (2,4,6-trinitrotoluol-ekvivalens) nukleáris robbantás tízezer emberi áldozattal jár. Mivel 1957-ig már ötven megatonna TNT-ekvivalens ${ }^{4}$ robbantást hajtottak végre, félmillió áldozattal lehetett számolni. A dolgok iróniája az volt, hogy az adott történelmi pillanatban Szaharov riasztó figyelmeztetéssel felérö becslései összhangban voltak Hruscsov politikai érdekeivel. A szovjet vezető ugyanis moratóriumot hirdetett a kísérleti robbantásokra, míg az amerikaiak folytatták saját robbantásaikat. Szaharov cikkét a szovjet orgánumok nagy hírveréssel és Hruscsov szerkesztői változtatásaival közölték, amelyek növelték a veszélyt indikáló számokat, és amelyeket Hruscsov Szaharovval nem egyeztetett. Amikor aztán Hruscsov politikai érdekei úgy kívánták, gátlástalanul felújította a kísérleti robbantásokat, és Szaharov semmit sem tehetett az értelmetlen robbantások megakadályozására.

Szaharov még az Arzamasz-16 munkatársa volt, amikor 1964-ben aktív szereplője lett az akadémikusi választásoknak. Fellépett Liszenko pártfogoltjának érdemtelen megválasztása ellen, és azt más akadémikusok fellépésével összhangban sikerült megakadályozni. Szaharov 1968-ban hagyta el a nukleáris laboratóriumot, és tért vissza eredeti munkahelyére, a FIAN-ba. Addigra már érzékenynyé vált a politika iránt. Az első időkben csak általános kérdésekben nyilvánult meg. Aláírt egy a Sztálin rehabilitálását ellenző tiltakozást. Jelen volt egy néma tüntetésen, amelyet a törvénytelenségek elleni tiltakozásul a szovjet alkotmány ünnepén rendeztek a moszkvai Puskin téren. Csatlakozott a Bajkál-tó ipari szeny-

\footnotetext{
${ }^{4}$ Összehasonlításul: a Hirosimára ledobott atombomba ereje 15 kilotonna TNT-ekvivalens körül volt. Ebben az esetben nem alkalmazható Szaharov becslése az emberáldozatok számát illetően, mert a nagyvárosra ledobott bomba közvetlenül ölt.
} 
nyezése ellen tiltakozó mozgalomhoz. Akadémikusi státusza és mint a Szocialista Munka Hőse háromszoros kitüntetettje óriási tekintélyt kölcsönzött bármely mozgalomnak, amelyik sorai között tudhatta. A hatóságok letartóztattak tüntetőket és tiltakozókat, de Szaharovhoz nem nyúltak.

\section{AZ EMBERI JOGOKÉRT}

Szaharov egyre inkább részt vett egyének jogainak védelmében. Tárgyalásokra járt, harcolt a vallási szabadságért, az antiszemita diszkrimináció ellen, az emigrálás jogáért, és számtalan ügyet karolt fel. Ismertségét a nyugati sajtó is fokozta, és Szaharov is felismerte a sajtónyilvánosság erejét. Mérföldkő volt a Reflections on Progress, Peaceful Coexistence, and Intellectual Freedom címü pamfletjének megjelentetése 1968-ban. A megjelenés éve különlegesen mozgalmas volt - itt utalok a nyugat-európai diákmozgalmakra, valamint a ,prágai tavaszra” és brutális elfojtására. A világ közvéleménye szomjazott az iránymutatásra, és ezt vélték felfedezni Szaharov szavaiban. A pamflet legalább tizennyolc millió példányban fogyott el, a publikációs sikerlistán csak Mao Ce-tung és Lenin müvei előzték meg, míg olyan sztárszerzőket utasított maga mögé, mint Georges Simenon és Agatha Christie. A pamflet foglalkozott a termonukleáris háború veszélyeivel, a demokrácia kérdéseivel, a szellemi szabadsággal, a fejlett és feltörekvő országok életszínvonala és lehetőségei közötti áthidalhatatlannak látszó szakadékkal és más, hasonló súlyú kérdésekkel. A hatalom birtokosai sok helyen érezték magukat veszélyeztetve Szaharov nézetei által, de sehol sem annyira, mint a Szovjetunióban. A szovjet hatalom paranoiásan rettegett az értelmiségiek véleményétől, és üldözte azokat, akik elolvasták, netán terjesztették Szaharov pamfletjét. A szovjet hatalom szemében addig elsősorban az írók és költők, szociológusok és környezetvédők jelentették a legföbb ellenséget, akik szellemiségükön kívül semmivel sem rendelkeztek. A hatalom most új jelenséggel találta szemben magát, egy fizikus világtekintéllyel, akadémikussal, akinek a tevékenysége döntően hozzájárult a Szovjetunió szuperhatalmi pozíciójához. Ugyanakkor Szaharov szinguláris jelenség volt, magányos hős, aki azonban megrengette a legyőzhetetlennek és öröknek hitt birodalmat. Amikor neki ítélték az 1975-ös Nobel-békedíjat, nem engedték kiutazni a díj átvételére, és szimbolikusnak is tekinthetö, hogy a dijátadáskor (ahol felesége képviselte) Szaharov Vilniuszban tartózkodott egy másik emberi jogi aktivista tárgyalásán. A következő években Szaharov megsokszorozott erővel és tekintéllyel folytatta küzdelmét az emberi jogok tiszteletben tartásáért és más emberi jogi harcosok kiszabadításáért. Olyan drasztikus eszközökkel is élt, mint az éhségsztrájk. A hatóságok tehetetlenek voltak vele szemben, mígnem 1980 januárjában végletes cselekvésre szánták el magukat. Rendeletben fosztották meg Szaharovot minden kitüntetésétől, és bírósági tárgyalás 
nélkül Gorkijba (korábban és most újra Nyizsnij Novgorod) számüzték. A város zárt terület volt külföldiek számára, ami hozzájárult a kiválasztásához. Egyetlen eszköztől tartózkodtak, nem semmisítették meg akadémiai tagságát. A hétéves gorkiji száműzetés idején egy-két évente engedélyezték egy-két FIAN-beli fizikus akadémikusnak, hogy meglátogassa Szaharovot. Számára ez jelentett, ha mégoly csekély kapcsolatot is a tudományos világgal. Egész idő alatt nagyszámú KGB-ügynök foglalkozott azzal, hogy zaklassa, ellopja a kéziratait, és minden módon megnehezítse az életét. Szaharov még ezek között a körülmények között is mindent elkövetett, hogy kiálljon mások érdekében és védelmében. Erkölcsi tartását jellemzi az is, hogy kínosan tartotta magát a korábbi titkos munkához szükséges biztonsági elő́rásokhoz. Előfordult, hogy akadémikus látogatóival, akiknek szintén megvolt a biztonsági engedélyük, titkosított tudományos témáról beszélgetett. Egy ponton azonban Szaharov arra hivatkozva állította meg az eszmecserét, hogy bár a beszélgetésben részt vevőknek van biztonsági engedélyük, a beszélgetést titokban lehallgató KGB-ügynököknek valószínüleg nincs.

\section{A SZUTA A HÁTTÉRBEN}

Szaharovot Leonyid Brezsnyev pártfőtitkár uralma idején számüzték, de helyzete nem változott a soron következő szovjet vezetők, Jurij Andropov és Konsztantyin Csernyenko alatt és Mihail Gorbacsov fötitkárságának első 18 hónapja idején sem. Amikor a hatalom a legkülönbözőbb eszközökkel igyekezett megtörni Szaharovot, ebből a Tudományos Akadémia sem maradhatott ki. Még a brezsnyevi időkben, 1973-ban az Akadémia negyven tagja aláírt és publikált egy levelet, amelyben elítélték Szaharov tevékenységét. A levél aláíróit gátlástalan eszközökkel gyüjtötték össze, volt, akitől meg sem kérdezték, hogy hajlandó-e aláírni, de odaírták a nevét. Néhány esetben azonban hozzájárulás nélkül ezt nem merték volna megtenni. Petr Kapica megtagadta az aláírást, a Szaharovval sok éven át együttműködő fizikus kollégájától, Jakov Zeldovicstól meg sem kérdezték, hogy aláírja-e. Amikor az Akadémia elnökét, Anatolij Alekszandrovot felhívták, nem tudott a telefonhoz menni, mert felesége szerint részeg volt, így az ő aláírása sem szerepelt. A nyilvánosság azonban csak arról értesült, hogy negyven tudományos tekintély elítélte Szaharov akadémikust. Akik ismerték ezeket a levélírási akciókat, nem tulajdonítottak jelentőséget ennek a levélnek. Más volt a helyzet azzal az akadémikusi levéllel, amelyet 1983-ban hoztak nyilvánosságra, amely a legdurvább nyelven támadta Szaharovot, és amely két jellegzetes ponton különbözött az előzőtől. Ekkor Szaharov már belső számüzetésben volt teljes kiszolgáltatottságban, miközben a KGB folyamatosan üldözte. Ez volt az egyik különbség. A másik az, hogy ezt a levelet mindössze négyen írták alá, ami nagyobb súlyt jelentett, mint az előző levél negyven aláírása. A négy aláíró mindegyike valóban elítélte 
Szaharov tevékenységét, és valóban aláírta a levelet. Az egyik aláíró Alekszandr Prohorov Nobel-díjas lézerkutató fizikus volt. Ez a cselekedete szomorú foltot hagyott ragyogó pályáján. Érdekes hozzátenni, hogy a jelenlegi orosz hivatalosság elismeréssel tekint a néhai Prohorov közéleti tevékenységére. Egyedüliként a szovjet korszak fizikus óriásai közül, neki állítottak nemrégiben (2015) nagy méretű szobrot Moszkva egyik legforgalmasabb pontján.

Láttuk, hogy Szaharovot megfosztották kitüntetéseitől, és számüzték, de továbbra is tagja maradt a Tudományos Akadémiának. Volt azonban egy pont a számüzetés idején, amikor helyzete annyira kilátástalanná vált, hogy saját maga vetette fel a tagság kérdését. Ez 1984-ban, a számüzetés negyedik évében történt. Azzal fordult a SZUTA elnökéhez, hogy ha az Akadémia nem képes segíteni problémáin, lemond akadémiai tagságáról. Ez a lépés egzisztenciálisan fenyegetett helyzetet idézett volna elő számára, de szerencsére erre már nem került sor.

\section{SZAHAROV ÉS GORBACSOV}

A Szovjetuniónak 1985 márciusától új vezetője lett az ötvennégy éves Mihail Gorbacsov személyében. Hogy le akarta-e bontani a szovjetrendszert, vagy csak belekényszerült a változásokba, ma is vitatott. Tény, hogy Gorbacsov uralma idején Szaharovot még tizennyolc hosszú hónapig számüzetésben tartották, miközben folytak a tárgyalások szabadon bocsátásának feltételeiről. Még ebben az időben is előfordult, hogy Szaharov éhségsztrájkra kényszerült. Szaharov szerint amerikai és elsősorban az USA Nemzeti Tudományos Akadémiája által gyakorolt nyomásnak is szerepe volt abban, hogy szabadon engedték. Később az is kiderült számára, hogy szabadon engedését Gorbacsov tanácsadói szorgalmazták már akkor, amikor a fötitkár még nem hajlott erre. Ma sok helyen olvasható olyan megfogalmazás, miszerint 1986 decemberében Gorbacsov „meghívta” Szaharovot, térjen vissza Moszkvába, és folytassa hazafias tevékenységét. A valóságban Gorbacsov „megengedte” a visszatérését. A következő években - és már mindössze három év maradt vissza Szaharov életéből, de a Szovjetunióból sem sokkal több kettejük pályája sokszor kereszteződött. Kezdetben még szinte megközelíthetetlen volt számára a főtitkár/elnök, később közvetlen összecsapásaikra is sor került. Szaharov hazájában is, és nem csak egy kis „okvetetlenkedő” értelmiségi réteg számára, fontos politikai tényező lett. Megnyilatkozásait azért is érdekes felidézni, mert azokat nem homályosítja el az egyre növekvő időbeli távolság Gorbacsov szempontjából jótékony köde.

Szaharov élesen bírálta Gorbacsovot, amikor a fötitkár bejelentette, hogy nincsenek politikai foglyok, és senkit nem üldöznek nézeteiért, miközben tömegével voltak, és egy jeles képviselőjük éppen abban az időben meg is halt a börtönben. Szaharov fellépett az ellen, ahogyan a szovjet hatóságok az első időkben jelenték- 
telen balesetként kezelték a csernobili katasztrófát, amivel magát Szaharovot is megtévesztették. Később Szaharov azokról a tapasztalatairól írt, amelyek szerint Gorbacsov az általa elnökölt tanácskozásokon diktatórikusan viselkedett, úgymond a demokrácia védelmében szívesen nyúlt nem demokratikus eszközökhöz, és igyekezett korlátlan hatalmat összpontosítani saját kezében. Óriási szakadékot tapasztalt Gorbacsov szavai és tettei között az általa képviselt gazdaságpolitikában és társadalompolitikában egyaránt, és elöítéletei gyakran befolyásolták politikáját. Gorbacsov jellemzően olyan politikai vezető volt, aki még nem szokott ahhoz, hogy választásokat nyerjen meg a politikai hatalom kivívásához. Gorbacsovot érezhetően irritálta Szaharov igazi prodemokratikus attitüdje és szókimondása, és ennek többször hangot is adott. A glasznoszty politikáját nem tudta saját magára is alkalmazni, és igyekezett korlátozni a nyilvánosságot politikai tevékenységében. Szaharov próbálta megállítani Gorbacsov egyeduralmi törekvéseit, miközben elismerte, hogy a szovjet vezető színre lépése a korábbiakhoz képest a pozitív változások záloga volt.

\section{SZAHAROV TUDOMÁNYA}

Szaharov tudományos eredményeit nagy nemzetközi elismerés övezi, de életének csak rövid és ritka periódusaiban foglalkozott felfedező tudománnyal. Zavartalannak azt a FIAN-ban töltött három évet tekinthetjük, amelyet kandidátusi munkájával töltött. Amint már fentebb utaltam rá, ez a munka és a védés aprólékosan dokumentált; olvasásuk élmény. Fizikai kutatásaiba beletartozott a termonukleáris bombán folytatott munka egyik-másik szakasza is. Nemcsak Szaharov, de más fizikusok is, köztük Enrico Fermi, nem tekintették veszteségnek a nukleáris bombák kifejlesztésére áldozott idejüket. Itt nem arra gondolok, hogy a béke megőrzése érdekében végzett tevékenység nem lehetett veszteség, hanem kifejezetten a fizika müvelésének szempontjából. Ugyanis mindannyian érdekes fizikának tartották, tele kihívásokkal, Fermi egyenesen a ,jó fizika” kifejezést használta. A titkos nukleáris laboratóriumban eltöltött két évtizede során azonban Szaharovnak alig akadt lehetősége más fizikára. Ami volt, azt elsősorban fizikus társa, a nála nyolc fontos évvel idősebb Jakov Zeldovics közvetítésének köszönhette. Fontosnak neveztem a nyolc év különbséget, mert az még a háború elött izgalmas tudományos feladatok megoldásával telt el. Zeldovicsnak több moszkvai kapcsolata volt, mint Szaharovnak, jobban hozzájutott az új tudományos eredményekhez és aktivitása ösztönzőleg hatott a zárkózottabb Szaharov tevékenységére. A Moszkvában, 1968-tól újra a FIAN-ban töltött időszak és a számüzetés kezdete, 1980 közötti évek egyre kevésbé jelentettek fizikát, mert egyre inkább lefoglalták az emberi jogok védelmének ügyei. Ezután következett a számüzetés, amit a fizikai megpróbáltatások és a nemzetközi irodalom hiánya 
egyaránt nehezített. Szaharov különlegességére jellemző, hogy ebben az időben is születtek új tudományos eredményei. Moszkvába történő 1986. decemberi viszszatérését követően azonban már alkotásra alig volt lehetősége.

A fentiek fényében szinte meglepö, de tudományos munkáit egy több mint ötszáz oldalas, sủrün nyomtatott, a FIAN kiadásában megjelent könyv foglalta össze 1995-ben. Méltatói legfontosabb eredményeit elsősorban három területen tartják számon, a plazmafizikában, az elemi részecskék fizikájában és a kozmológiában. A szovjet fizikusok között Szaharov javasolta elsőként lézer alkalmazását ellenőrzött termonukleáris reakciók megvalósítására. Ugyancsak ő vetette fel először azt a lehetőséget, hogy a fúziós reaktorból származó neutronokat használják fel hasadó anyagok előállítására, amelyek atomreaktor üzemanyagául szolgálhatnak. Módszert javasolt szuper erős mágneses terek létrehozására. Más szovjet fizikusokkal együtt kezdeményezte az ún. tokamak létesítését, amelyben nagy erősségủ mágneses tér segítségével tórusz alakú plazmát hoznak létre, ami elvezethet a termonukleáris, fúziós energiatermeléshez.

Az elemi részecskék fizikájában következtetett egyes elemi részecskék tömegére az anyag legalapvetőbb építőköveinek, az ún. kvarkoknak a szerkezetéből. Ezen a területen született meg valószínüleg legjelentősebb, de mindenképpen legismertebb eredménye. Ez egy valószínűsíthető magyarázat az univerzum barion-aszimmetriájára. A proton és a neutron barion, és jórészt ezek a részecskék alkotják a világegyetem ismert tömegét. A barion-antibarion aszimmetria ahhoz az alapvető kérdéshez kapcsolódik, hogy miért anyagból - és nem antianyagból - áll a világunk. Ezt úgy is megfogalmazhatjuk, hogy miért van egyáltalán anyag az univerzumban. Az ősrobbanáskor, a rendkívül magas hőmérsékleten óriási energia halmozódott fel, ami részecskék és antirészecskék keletkezéséhez vezetett. A hőmérséklet fokozatos csökkenésével a részecskék és az antirészecskék páronként megsemmisítették egymást. Ha azonos mennyiségben lettek volna jelen, akkor kiürült volna a világegyetem. Tehát valamennyivel, még ha kevéssel is, több anyagnak - vagyis kevesebb antianyagnak - kellett lennie a korai univerzumban. Ez mutatkozik meg a barion-aszimmetriában, és ebből következik, hogy a világegyetemben anyag van. De miért volt eleve több anyag, mint antianyag? Erre a nagy kérdésre még mindig nem tudjuk a választ, de Szaharov megkönynyítette ennek a válasznak a keresését. 1967-ben három olyan feltételt állított fel, amelyeket a majdan megtalált válasznak teljesítenie kell. Az első feltétel szerint létezniük kell olyan folyamatoknak, amelyek képesek a barionszám megváltoztatására. A második szerint a természeti törvényekben meg kell jelennie valamilyen eltolódásnak, amely az antianyag helyett az anyagnak kedvez. A harmadik szerint a barionszám megváltoztatására képes folyamatok termikus egyensúly hiányával jellemzett körülmények között alakulnak ki. A termikus egyensúly hiánya arra vonatkozik, hogy az ősrobbanás óta a világegyetem a folyamatos hülés állapotában van. 
A barion-aszimmetria elmélete összekapcsolja az elemi részecskék fizikáját és a kozmológiát. A kozmomikrofizika tudományterületének kialakulásában Szaharov eredményei is szerepet játszottak. Foglalkozott a táguló világegyetem problémájával és az anyag nem egyenletes eloszlásával, az idő irányának megfordulásával, a negatív térgörbülettel és a véges nagyságú kozmológiai állandóval. Jelent meg munkája a gravitáció alternatív elméletére vonatkozóan is, amely Albert Einsteinétől eltérően tárgyalja ezt a jelenséget, messzemenő lehetséges következményeivel együtt.

\section{SZAHAROV ÉS TELLER}

A két tudóst elsősorban az kapcsolja össze, hogy mindkettőt a hidrogénbomba atyjaként emlegetik, Teller Edét az amerikai, Szaharovot a szovjet hidrogénbomba atyjaként. Kétséges, mennyire elismerő vagy éppen elítélő ez a cím, de abban elég széles körü az egyetértés, hogy a kölcsönös elrettentés politikája, akármilyen rémségesen hangzik, hosszú ideig visszatartotta a szuperhatalmakat egymás megtámadásától. Amikor 1985-ben, Szaharov számüzetése idején tiszteletére New Yorkban megjelentettek egy antológiát (Andrei Sakharov and Peace), az egyik fejezetet Teller Ede írta (Lozansky, 1985, 107-118.). Teller megjegyzi, hogy vannak közöttük hasonlóságok, de az eltérések jóval jelentősebbek, és ezért kettőjük története nem tekinthető párhuzamosnak. Személyesen csak egyszer találkoztak, erre 1988. november 16 -án egy, a Teller tiszteletére rendezett ünnepségen, Washingtonban került sor. Csak rövid beszélgetésre volt lehetőségük. Szaharov felszólalt, és röviden kifejtette az akkor vita tárgyát képező Stratégiai Védelmi Kezdeményezést (SDI) elítélő véleményét. Ez után el kellett mennie, hogy elérjen egy utolsó járatot elutazásához. Teller már csak távollétében mondhatta el, mennyire nem értett egyet Szaharovval, de érdemben nem vitatkozott vele, mert Szaharov véleményét a tudós tájékozatlanságával magyarázta. Tipikusan telleri vitamódszer volt, mert tudnia kellett, hogy Szaharov számára központi kérdésről volt szó, arról nem is beszélve, hogy Szaharov mennyire lelkiismeretesen készült fel minden megszólalására.

Szaharov egyik legfontosabb véleménykülönbségnek közöttük azt látta, ahogyan a kísérleti robbantások biológiai következményeit tekintették. Szaharov számára a biológiai veszélyeknek döntő szerepük volt abban, hogy ellenezte a további kísérleti robbantásokat. Teller hol azt emelte ki, hogy a károsodás mértéke elhanyagolható más veszélyforrásokhoz képest, hol azt hangsúlyozta, hogy a születési rendellenességek azt a megfizethető árat jelentik, amit a biztonságért meg kell adni.

Ami a tudósok társadalmi felelősségét illeti, Szaharov nem titkolta, hogy felelősnek tartja a tudósokat abban, hogy megoldást találjanak a legfontosabb politikai problémákra. Két dolog különösen nyugtalanította: a nukleáris pusztítás 
lehetősége és az egyének erkölcsi felelőssége a pusztítás megakadályozásában. Teller időről időre hangsúlyozta, hogy a tudósok felelőssége az új létrehozása, de a felhasználásról a társadalom (illetve megválasztott képviselői) döntenek. Véleménye tehát összhangban volt azokkal a szovjet vezetőkkel, akik bírálták Szaharovot azért, mert beleütötte az orrát a politikusok dolgába. Valójában azonban Teller aktívan igyekezett befolyásolni a döntéshozókat olyan ügyekben, amelyekben érdekelt volt.

Naívabb korszakukban mind Szaharov, mind Teller elképzelték, hogy idővel létrejöhet egy világkormány. Teller ezt 1947-ben vetette fel, és úgy gondolta, hogy egy világkormány technikai eszközökkel tudná megakadályozni a háborút. Szaharov 1968-ban rajzolt meg egy túl optimista világképet. Ebben 1980-ra a szovjet egypártrendszert többpártrendszer váltja fel, 2000-re megalakult volna a világkormány, és a szuperhatalmak összefogtak volna a világ szegényebb felének a megsegítésére.

Mindketten hangsúlyozták, hogy a hidrogénbombát nem egyedül hozták létre, és abban sokan mások is részt vettek. Teller részéről ez nem hangzott elég őszintének, mert pont Stanislaw Ulam közremüködésének jelentőségét igyekezett csökkenteni, akinek valójában fontos szerepe volt. Szaharov reálisan hangsúlyozta (a későbbi Nobel-díjas) Vitalij Ginzburg ötletének értékét és Zeldovics és mások részvételét. Ezen a ponton óriási kontraszt volt Szaharov és Teller között.

Mindkettőnek kiváló érzéke volt ahhoz, hogy egy megoldandó problémát először kvalitatívan ítéljenek meg, becsléssel legyen elképzelésük a megoldást illetöen, és csak aztán foglalkozzanak a részletekkel. Mindketten összegyeztethetőnek tartották a felfedező kutatást az alkalmazással, sőt, maguk is keresték az alkalmazhatóságot. Mindketten elkötelezett hívei voltak az atomenergia energiatermelésre történő felhasználásának. Tellernek évekig vezető szerep jutott az amerikai atomreaktorok biztonságos müködtetésének megteremtésében (erről az oldaláról kevés szó esik). Mindketten az atomreaktorok biztonságos működtetését a föld alá történő süllyesztéssel képzelték el. Már több mint harminc éve is mindketten elengedhetetlennek tartották, hogy új atomreaktorokat többé ne építsenek a felszínen, csak a föld alatt!

Mindketten szívesen foglalkoztak a tudomány ismeretterjesztő jellegü népszerüsítésével. Ami a nyilvános szereplést illeti, Szaharov visszahúzódó volt, nem szeretett rögtönözni, és nem volt gyakorlott vitatkozó. Teller élvezte a nyilvánosságot, és remekül csinálta. Kiválóan tudott vitatkozni, bár nem mindig tisztességesen.

Szaharov tisztelte Tellert, amikor az elvi alapokon érvelt véleménye mellett, függetlenül attól, hogy egyetértett-e Teller véleményével. A két különleges tudós életpályájának alakulása részletes összehasonlításért kiált, ami megérne egy külön tanulmányt. Alkalmazható-e rájuk a párhuzamos jelző? Mintha valóban a két életpálya párhuzamosan futott volna, de nem együtt, hanem inkább ellentétes irányban. 


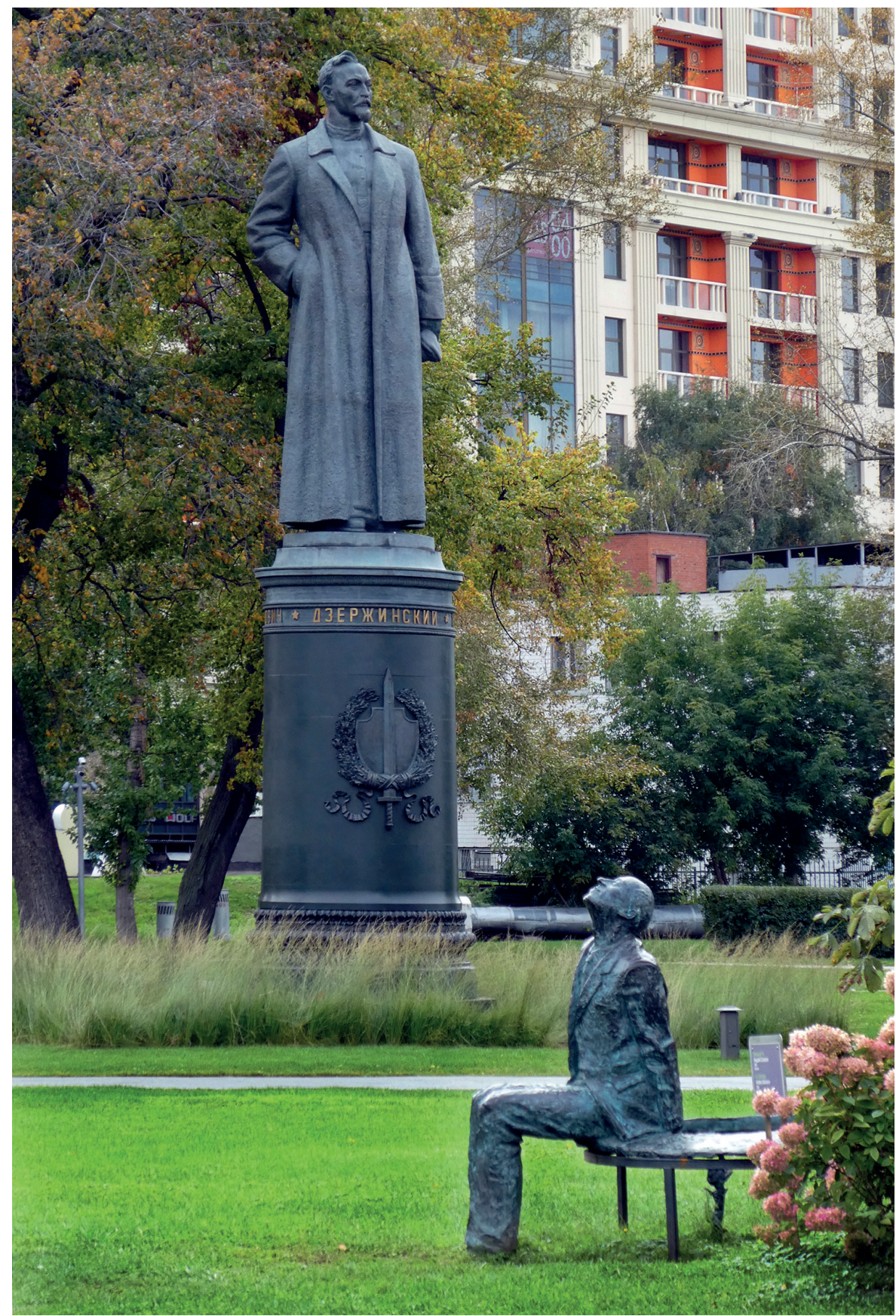

Feliksz Dzerzsinszkij (J. V. Vucsetics szobra 1958-ból) és Andrej Szaharov (G. V. Potockij szobra 2008-ból) a Muzeon Parkban (a szerző felvétele, 2016) 
A Muzeon Park Moszkva egyik központi kerületében van, benne egy nagy szoborparkkal, amely úgy indult, mint a budapesti Szoborpark. A letünt rendszer emlékműveit tervezték összegyüjteni benne, és egy darabig el is jutottak. Aztán a folyamat megrekedt, sok régi emlékmü a helyén maradt, a Muzeon Parkban viszon megjelentek olyan alkotások, amelyeknek nem volt közük a szovjet rezsimhez. Így alakulhatott, hogy ma egymás szomszédságában áll Feliksz Dzerzsinszkij és Andrej Szaharov szobra. Annak idején Dzerzsinszkij alapította meg a hírhedt KGB hírhedt elődjét (CSEKA, majd GPU, majd NKVD), és monumentális emlékmüve évtizedekig a Lubjanka téren, a KGB (ma FSZB) székháza elött állt. A Szaharov-szobor 2008-ból való, és ha nem lenne mellé írva, hogy kit ábrázol, egy békésen napozó öregúrnak gondolhatnánk. A két szobor együtt szimbolikus, mintha az önkényuralom és az emberi jogokért folytatott küzdelem került volna egymás mellé, egy sajátos David/Szaharov és Góliát/Dzerzsinszkij páros. Az emberi jogokért folytatott küzdelem sokáig reménytelennek látszott, de végül ez a törékeny ember legyőzte a legyőzhetetlennek tartott intézményt. Szaharov halálát követően hatalmasra nőtt tekintélye és tisztelete. A Szovjetunió összeomlásával, az orosz demokratizálódás kezdeti lépéseivel úgy tủnt, hogy Szaharov - a szovjet időkben kedvelt kifejezéssel - „teljes és végleges” győzelmet aratott a Dzerzsinszkijjel szimbolizált erők felett. Az utóbbi évek, már évtizedek, történései szerint azonban Szaharov győzelme nem volt sem teljes, sem végleges. Vajon jönnek-e majd új Szaharovok?

\section{IRODALOM}

Gorelik, G. - Bous, A. W. (2005): The World of Andrei Sakharov. New York: Oxford University Press

Hargittai I. (2014): Eltemetett dicsőség. Budapest: Akadémiai Kiadó

Lozansky, E. D. (ed.) (1985): Andrei Sakharov and Peace. New York: Avon Books

Sakharov, A. (1990): Memoirs. New York: Alfred A. Knopf

Sakharov, A. (1991): Moscow and Beyond 1986 to 1989. New York: Alfred A. Knopf

Сахаров, А. Д. (1995): Научные труды. Москва: ЦЕНТРКОМ 